\title{
The Menace of Leprosy in Manchuria.
}

\section{James L. Maxwell, M.D.}

WE province of Manchuria constitutes the largest province of the Republic of China, with an area of 1 some 363,700 square miles. The population is estimated at 24 millions, being but 66 to the square mile. $\left({ }^{1}\right)$ The country is rich in minerals, and the soil in many parts is very fertile, the province thus proving a great attraction to immigrants from less favoured parts of China. Immigrants have indeed come to Manchuria in a steady stream for many years, but the flow has been greatly intensified in the past three years owing to famine and anarchy in other parts of the Republic. The bulk of these immigrants come from Shantung and the Northern part of Kiangsu, and so great has their volume been that this constitutes one of the largest movements of population on record. The numbers are estimated at something like three million persons during the years 1927-1929.(2)

One of the dangers of such mass movements of population is that diseases common in the regions from which the immigrants come, and which are yet absent from the lands in which they settle, shall be carried and spread by them in the new country. Of such diseases leprosy is one of the most serious.

Manchuria has been regarded up to the last year or so as practically free from leprosy, but the danger of its introduction from without in connection with these mass movements of population has been fully recognised by those interested in the problem of this disease in China. $(8,4)$ 
To say that leprosy has been absent from Manchuria in the past is not strictly correct. For thirty or forty years one of the largest hospitals in that province has noted an occasional case. Such cases have, however, never amounted to more than two or three in a year, and have been confined to persons entering Manchuria from other provinces. A possible exception to this is a small, very limited area on the Korean border of the province, where leprosy is said to be indigenous. Final proof of this statement has, however, not been forthcoming.

The mass immigration of the past three years has come mainly from the province of Shantung and the northern part of the province of Kiangsu. Both these areas are well recognised as heavily infected with leprosy, and the disease in Shantung dates back for at least many centuries. The immigrants enter Manchuria mostly from the south, and while small numbers remain in the southern and central areas, the bulk of them move up to the more empty lands of the north of the province.

Moukden, the provincial capital, lies in the southern district, and is thus less affected by the stream of immigrants than are other areas. It is here, however, where the largest and most progressive modern medical institutions are to be found, and where an excellent Mission Medical College with large hospitals and a very extensive out-patient work is situated, and from which alone at present reliable statistics are to be obtained.

On a recent visit there the writer was enquiring into the leprosy situation, and the following information was obtained from the dermatological department :-

During the past few years the maximum number of lepers seen in this department was three or four, all old cases in visitors to Manchuria. During the first nine months of the current year (1930) between thirty and forty cases of leprosy had come to the department. It was doubtful, however, whether any of these were natives of Manchuria, though no special attention had been paid to this side of the question. The bulk certainly were immigrants from Shantung or North Kiangsu, except in the case of one or two children in whom the symptoms of the disease had manifested themselves some time after the families had settled in their new homes.

From this statement two deductions may fairly be drawn :-First, that leprosy is now to be found in southern Manchuria on a scale never before known. For if this 
number appeared among casual visitors to the dispensary, it is certain that the actual figures for lepers must be very much higher in this region; second, that in view of the fact that only a very small proportion of the mass of immigrants settle in the Moukden region, the vast bulk of them taking up land further north, it is practically certain that in the northern part of Manchuria the present incidence of leprosy must be relatively high.

It is of course uncertain how far the disease will continue to spread among the newcomers and as to how far it may develop among the original inhabitants of the province. In view, however, of the history of leprosy in other lands, it is at least safe to say that the present position in which neither treatment nor control of leper immigrants is being carried out constitutes a very serious menace to the province. This is particularly the case in that over 80 per cent. of the immigrants are men(5), and therefore intermarriage or concubinage on a large scale is certain to take place.

The situation evidently calls for very careful consideration, and for the carrying out of at least some simple steps for the control of the disease.

It might be possible to prevent the entry of further lepers by the institution of preventive measures at the points where immigrants enter the province. This, we fear, however, would be little more than locking the stable door after the horse has escaped. There is already this year (1930) a very rapid decrease in the stream of immigration, and this decrease would appear to be a progressive one. $\left(^{6}\right)$

A survey of the present situation is, however, urgently needed, and methods of treatment and, in certain cases, of segregation ought immediately to be instituted. Whether the authorities can be stirred up to take such steps, and whether, in view of the enormous costs of military enterprises to which the province is committed, enough money can be found to meet the urgent need is, we fear, at least doubtful.

\section{REFERENCES.}

(1) China Year Book, 1929-30, p. 3.

(2) Chinese Economic Fournal, vii, p. 755.

(3) Fowler. Leprosy in the Far East, 1929, p. 39.

(4) Maxwell. China Medical fournal, xliv, p. 802.

(5) Chinese Economic Fournal, vii, p. 755.

(6) Ibid., vii, p. 754. 